\title{
Retrovirology highlights a quarter century of HTLV-I research Kuan-Teh Jeang*
}

Address: Laboratory of Molecular Microbiology, NIAID, NIH Bethesda, Maryland 20892, USA

Email: Kuan-Teh Jeang* - kj7e@nih.gov

* Corresponding author

Published: 02 March 2005

Retrovirology 2005, 2:15 doi:10.1/86/1742-4690-2-15
Received: 23 February 2005

Accepted: 02 March 2005

This article is available from: http://www.retrovirology.com/content/2/I/15

(c) 2005 Jeang; licensee BioMed Central Ltd.

This is an Open Access article distributed under the terms of the Creative Commons Attribution License (http://creativecommons.org/licenses/by/2.0), which permits unrestricted use, distribution, and reproduction in any medium, provided the original work is properly cited.

\begin{abstract}
In 1977, Takatsuki and co-workers described in Japan a human malignant disease termed adult Tcell leukemia (ATL). Three years later, in 1980, Gallo and colleagues reported the identification of the first human retrovirus, human T-cell leukemia virus type I (HTLV-I), in a patient with cutaneous T-cell lymphoma. This month, Retrovirology commemorates these two land mark findings by publishing separate personal recollections by Takatsuki and Gallo respectively on the discovery of ATL and HTLV.
\end{abstract}

Retrovirology as a medical study first emerged in the early 1900s. In 1908, Ellermann and Bang reported on the transmissibility of avian leucosis by cell-free filtrates, suggesting the involvement of a virus [1]. Shortly afterward, in 1910, Rous demonstrated that chicken sarcomas were infectious and when inoculated into healthy birds induced tumors [2]. Today, a plethora of oncogenic animal retroviruses including bovine leukemia virus, feline leukemia virus, gibbon ape leukemia virus, Jaagsiektse sheep retrovirus, murine leukemia virus, mouse mammary tumor virus, reticuloendotheliosis virus, simian Tcell lymphotropic virus, and Walleye dermal sarcoma virus has been described.

Understanding how retroviruses cause cancer took a major step forward with the development of the cellular oncogene hypothesis in 1976. Thus Varmus, Bishop and colleagues [3] demonstrated that the viral oncogenes $(v$ onc) encoded by many retroviruses were captured originally from cellular sequences (i.e. c-onc). To date, three general models of retroviral transformation are accepted: a) over-expression of $v$-onc; b) cis-oncogenic effect from promoter insertion; and c) cis-oncogenic effect from enhancer insertion (Fig. 1A, B, C).
Although not yet fully understood, HTLV-I is believed to transform human T-cells neither through the acquisition of a c-onc nor by cis-insertion effects on the cellular genome. Pioneering molecular biology studies by Mitsuaki Yoshida and colleagues led to the delineation of the HTLV-I transforming gene, Tax [4]. Tax has no cellular homologue; and it works in trans to disrupt cellular checkpoints and destabilize genome integrity [5] leading to transformation (Fig. 1D). A more extensive discussion of the molecular biology of HTLV-I and its transforming function will be in an upcoming comprehensive review by Masao Matsuoka to be published in Retrovirology.

Two articles in this month's Retrovirology describe respectively the discovery of adult T-cell leukemia [6] and HTLVI [7]. 


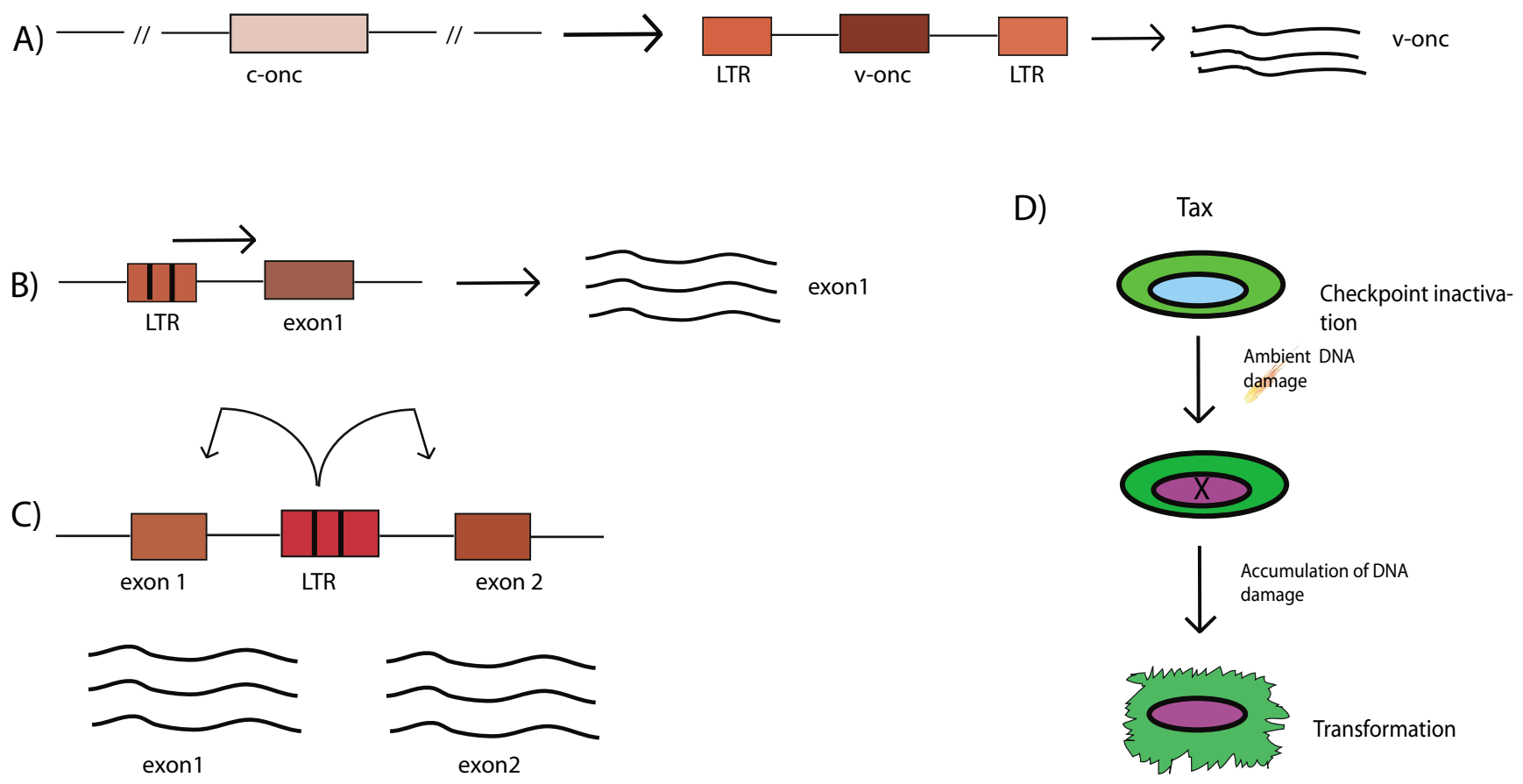

\section{Figure I}

Panels $A, B$, and $C$ show the three accepted ways by which a retrovirus may transform cells: capture of a c-onc and overexpression of $v$-onc by the provirus (A); promoter insertion upstream of a growth controlling cellular gene (B); and enhancer insertions either upstream or downstream of growth controlling cellular genes (C). Panel D shows the stepwise ways in which HTLV-I Tax oncoprotein may transform cells by i) inactivating checkpoints to induce tolerance of damaged DNA, and ii) permitting the accumulation of unrepaired DNA lesions which ultimately convert a normal cell to a transformed cell. 


\section{Acknowledgements}

I thank Anthony Elmo for help with preparation of manuscript.

\section{References}

I. Ellerman V, Bang O: Experimentelle Leukämie bei Hühnern. Zentralbl Bakteriol Parasitenkd Infectionskr Hyg Abt Orig 1908, 46:595.

2. Rous P: A transmissible avian neoplasm. (Sarcoma of the common foul). J Exp Med 1910, 12:696.

3. Stehelin D, Varmus $H$, Bishop JM, Vogt PK: DNA related to the transforming gene(s) of avian sarcoma viruses is present in normal avian DNA. Nature 1976, 260:170-173.

4. Yoshida M: Multiple viral strategies of HTLV-I for dysregulation of cell growth control. Annu Rev Immunol 200I, I 9:475-496.

5. Jeang KT, Giam CZ, Majone F, Aboud M: Life, death, and Tax: role of HTLV-I oncoprotein in genetic instability and cellular transformation. J Biol Chem 2004, 279:3 1991-31994.

6. Takatsuki K: Discovery of adult T-cell leukemia. Retrovirology 2005, 2:16.

7. Gallo RC: The discovery of the first human retrovirus: HTLVI and HTLV-2. Retrovirology 2005, 2: 17.

Publish with Bio Med Central and every scientist can read your work free of charge

"BioMed Central will be the most significant development for disseminating the results of biomedical research in our lifetime. "

Sir Paul Nurse, Cancer Research UK

Your research papers will be:

- available free of charge to the entire biomedical community

- peer reviewed and published immediately upon acceptance

- cited in PubMed and archived on PubMed Central

- yours - you keep the copyright

Submit your manuscript here:

http://www.biomedcentral.com/info/publishing_adv.asp 